\title{
1. Expanding the boundaries of institutional analysis in the transitional periphery
}

\section{Dilshod Makhmadshoev}

\section{INTRODUCTION}

Over the last two decades, institutional theory has provided scholars from various backgrounds with powerful and effective theoretical tools to probe into the post-socialist transition economies. Researchers, particularly in the fields of international business and small business and entrepreneurship, benefited significantly by drawing on neo-institutional perspectives to explore and explain the various effects of unstable institutional settings and embedded institutional factors on firm behaviour in these environments. However, it is highlighted here that the neo-institutionalist approach, and in particular the 'new institutional economics' lens, tends to represent the most dominant approach utilized by scholars with an interest in post-socialist economies. While this perspective remains powerful and effective to this day, this chapter proposes that research in this area can potentially benefit in important ways from expanding the boundaries of institutional analysis by integrating insights from two emerging but hitherto underexploited institutional perspectives, namely the "varieties of transition' approach (e.g., Havrylyshyn, 2006; Lane and Myant, 2007; Myant and Drahokoupil, 2011), which is an alternative to the mainstream comparative capitalism, and a more actor-centred perspective on institutional change, which is inspired by the works of Campbell $(1997,2004)$.

The first key observation regarding the current thinking on institutions in the context of transition economies is that it has not placed adequate emphasis on emerging variations in institutional environments among these countries. The process of transition in post-socialist states has not followed the previously anticipated linear progression towards Western models of capitalism (Makhmadshoev et al., 2015). Thus, exploring questions relating to institutional divergence becomes ever more important. Despite the popularity of institutional approaches in studying transition 
economies, research on the transitional periphery within business studies has remained largely silent in acknowledging the divergent transition paths and the implications of this institutional divergence on firm behaviour. The second key observation is that surprisingly little attention is paid to the role of actors as agents of institutional change, and to the mechanisms they deploy to achieve this change. Thus, it is proposed here that integrating insights from comparative capitalism and a theory of institutional change can enrich the current thinking on institutions and the firm in the transitional periphery.

This chapter will first provide an in-depth review of the new institutional economics (NIE) approach and how it is utilized in selected studies by international business (IB) and small business and entrepreneurship scholars with empirical focus on transition economies, highlighting its important explanatory capabilities. It will then introduce the two emerging institutional perspectives and highlight their relevance for the transitional periphery. In analysing the relevance of the varieties of transition (VoT) approach, it draws on some examples from empirical fieldwork conducted in Kyrgyzstan and Tajikistan. This chapter is partially based on insights obtained from this fieldwork in the Central Asian periphery, and further advances some of the conceptual ideas that were originally developed and published in contributions by Makhmadshoev et al. (2015) and Makhmadshoev and Crone (2014).

\section{NEO-INSTITUTIONAL APPROACH (NEW INSTITUTIONAL ECONOMICS)}

Institutional theory became increasingly prominent in the social sciences during the latter part of the twentieth century and has since attracted considerable attention from scholars in various fields, including economics, political science and sociology. It is widely recognized as one of the dominant approaches to understanding organizations (DiMaggio and Powell, 1983; Tolbert and Zucker, 1996; Scott, 1995). It is used in examining and explaining the importance of the wider social and cultural environments on organizational actions, organizational structures and organizational practices (Dacin et al., 2002; Kostova and Roth, 2002; Scott, 2008). Institutional thought has also revolutionized the study of economics and economic systems, and has been rigorously deployed in challenging some of the core arguments of the mainstream (neoclassical) economic theory (Coase, 1998; North, 1990).

Perhaps it is helpful to highlight that the body of knowledge regarded as institutional theory encompasses two distinctive streams: the early 
institutionalist approach and the neo-institutionalist approach (Furubotn and Richter, 2000; Scott, 1995). The development of institutional theory was initiated by the so-called early institutionalists (pre-1970s). However, this approach is said to have attracted increased criticism for being largely descriptive and lacking in theory (Coase, 1998; Scott, 2008). The work of early institutionalists was also strongly challenged for its inadequate focus on organizations and, crucially, for its failure to make a distinction between institutions and organizations (Scott, 1995). As a result, a new institutionalist approach (neo-institutional theory) has since emerged, which puts explicit emphasis on organizations and differentiates institutions from organizations (North, 1990; Scott, 2008). Thus, it can be argued that much of what is acknowledged today as 'institutional theory' constitutes the neo-institutionalist approach. This neo-institutionalist approach, in turn, is dominated by two major schools of thought, broadly known as: (1) the 'organizational institutionalism' - where institutions are viewed as inter- and intra-organizational forms, practices and activities that are enforced through coercive, mimetic and normative mechanisms, and which also tends to favour the terminology of regulative, normative and cognitive institutions (e.g., DiMaggio and Powell, 1983; Kostova and Roth, 2002; Scott, 1995); and (2) the 'new institutional economics' - which views institutions as 'the rules of the game' and favours the terminology of formal and informal institutions (e.g., Furubotn and Richter, 2000; North, 1990, p. 3; Williamson, 1981). It is the latter which is adopted more widely within business and management research on transition economies.

Though the new institutional economics (NIE) perspective is associated primarily with the works of Coase (1937), Williamson (1981) and North (1990), it is North who is more widely considered to have contributed significantly to bringing institutions to the forefront of economic development debate (North, 1987, 1990). Furthermore, by emphasizing the distinction between institutions (rules of the game) and organizations (players in the game) and by categorizing institutions into formal and informal types, and incorporating their enforcement mechanism into the analysis, North (1990) developed and proposed a powerful analytical framework for the study of institutional influences on economic behaviour and performance.

\section{Moving On through the 'Rules of the Game' Metaphor}

Institutions are 'the rules of the game in a society' (North, 1990, p. 3). They are forms of constraints created by humans to shape, structure and guide individual and organizational interactions and reduce uncertainties in everyday exchanges. Davis and North $(1971$, p. 6) define an institutional 
environment as 'the set of fundamental political, social and legal ground rules that establishes the basis for production, exchange and distribution'. Institutions can be formal and informal (North, 1990). Formal institutions include rules (political rules, economic rules, judicial rules and individual contracts), regulations, laws and written constitutions. Informal institutions consist of conventions, customs and social norms of behaviour, which are influenced by culture and are often distinctive to particular societies (North, 1990, 1991, 2005).

The main premise of the institutional perspective advanced by North $(1990,2005)$ is that institutions influence economic performance and shape economic outcomes (Furubotn and Richter, 2000; Williamson, 1998). It is by demonstrating the existence of positive transaction costs that the NIE thinking developed a strong case for challenging the mainstream (neoclassical) economic reasoning, and as a result suggested a new way of analysing economic systems and economic exchanges. North (1987, p. 419) states that 'what economists have not realized until recently is that exchange is not costless'. He goes on to assert that the cost of transacting is fundamental to the performance of economies and economic actors, including firms (North, 1987, 1990). Thus, transaction cost analysis has become a particularly important instrument in understanding how institutions influence the behaviour and performance of economic actors. 'Transaction cost' is a broad term that includes a range of costs associated with creating and operating an economic system, as well as those associated with creating and operating a new enterprise (Furubotn and Richter, 2000). Importantly, North (1990) also emphasizes that transaction costs are 'part of the costs of production' (ibid., p.28), and include a broad range of measurable costs, such as official fees and formal expenses, as well as 'hard-to-measure costs' (ibid., p. 68), such as costs of acquiring information and a wide range of informal costs, such as bribes and informal payments.

Uncertainty and transaction costs are the two closely interconnected dimensions in the study of institutions. Some degree of uncertainty, caused by political, economic or social factors, is generally present in any environment, which in fact explains the existence of positive transaction costs (Williamson, 1997). The role of institutions, as North (1990) crucially explains, is to reduce this uncertainty and provide stability when firms engage in a particular type of economic activity. However, this may not always be the case, as institutional frameworks are dynamic and evolving in nature. For uncertainty to remain low, institutions 'must be well-designed and properly maintained' (Furubotn and Richter, 2000, p. 7). Therefore, in environments where institutions are weak or poorly implemented, uncertainty tends to be high, which in turn results in high transaction costs 
for economic actors. This assumption is particularly evident in the analysis of the institutional environments of the former communist countries, including those in the periphery (Makhmadshoev and Crone, 2014; Peng and Heath, 1996; North, 1990, 1997).

North $(1987,1990)$ draws particular attention to growth benefits gained from participation in trade, but more importantly provides an explanation as to how institutional frameworks influence the process of participation in trade. The NIE argues that the idea of perfect market information is highly abstract, thus competition in markets (or in an economy) may not always be perfect or fair (Furubotn and Richter, 2000). Institutional frameworks, largely through formal state policies and regulatory mechanisms, play an important role in establishing and maintaining competitive conditions in markets. However, institutions differ from country to country, therefore in societies where the rules of competition are not well established or not properly administered, firms may face high transaction costs and limited opportunities for growth and expansion. This provides a partial explanation as to why some countries and their firms are more competitive and more successful when participating in international trade (Hall and Soskice, 2001).

The broader conceptualization of the institutional environment also encompasses the role of organizations (that is, non-firm organizations). Analysing organizations in this way, however, does not suggest disregarding the all-important distinction made between institutions (as the rules of the game) and organizations (as players of the game). North (1990) emphasizes the importance of conceptually distinguishing institutions from organizations. However, he further clarifies that this should not necessarily exclude organizations from the analysis, for sometimes it may be unreasonable to separate the analysis of the rules of the game from different organizations, agencies and associations that enforce, monitor and facilitate these rules. North $(1990$, p. 4) states that 'when we examine the costs that arise as a consequence of the institutional framework we see they are a result not only of that framework, but also of the organizations that have developed in consequence of that framework'. Thus, the analysis of institutional environments needs to focus not only on specific rules and norms, but can also include organizations that provide institutional support to economic actors in achieving their objectives and those that act as enforcers of rules and regulations.

One of the main shortcomings of the North-inspired institutional approach relates to its conceptualization of informal institutions. North recognizes certain difficulties in providing a clear-cut definition of informal institutions, mainly because the understanding of informal institutions in the NIE often overlaps with the sociological perspectives on network 
theory (Granovetter, 1973; Murdoch, 2000) and social capital (Coleman, 1988; Granovetter, 1985; Woolcock, 1998). This chapter adheres to the understanding of informal institutions informed by the NIE, as it is deemed more appropriate in identifying specific informal institutions at the national level, particularly in transition economies, and understanding how they influence firm behaviour. What North's and his NIE associates' contributions to the wider institutional theory suggest is that institutional environments of countries are a mix of economic, political and social structures that define and enforce the fundamental rules of production, interaction and exchange. This may include conditions of access to means of production as well as the more specific regulations concerning international trade and entry into specific industries. Thus, institutions not only influence the nature of activities of firms, but at a more fundamental level also affect the various opportunities available to them.

\section{Utility of NIE in IB and SME and Entrepreneurship Research on Transition Economies}

The North-inspired institutional approach has established itself as a dominant analytical tool for understanding the effects of institutions in transition economies and analysing economic activities of firms in these environments. The distinction of formal and informal institutions has been particularly pertinent in this respect. The institutional approach states that economic activities of firms are influenced not only by formal rules, but also by a range of informal rules (North, 1990; Peng, 2003). It also suggests that when formal rules are weak and inefficient, informal rules become more influential and gradually replace formal rules. Given that transition economies are undergoing a radical structural and institutional change, especially in terms of formal institutions, it is informal institutions that often take over and govern economic activities in such environments (North, 1990; Peng and Heath, 1996). The application of an institutional approach focuses attention on how the lack of formal rules may lead to increased uncertainty, and thus to high transaction costs for firms (North, 1990).

In recent years, institutions (or 'an institution-based view') have become a major focus in the IB and strategic management research community, alongside the more established industry-based and resource-based views of (international) strategy (Dunning, 2004; Meyer and Peng, 2005; Mudambi and Navarra, 2002; Peng, 2004; Peng et al., 2008). This can be observed from a growing number of Special Issues on the topic of institutions and IB in top-ranking academic journals (notable examples include the Journal of International Business Studies Special Issues in 2008, Vol. 39 
and 2010, Vol. 41; and the Journal of International Management Special Issue in 2008, Vol. 14, with specific empirical focus on transition economies) and edited books dedicated to the topic (a notable example Wood and Demirbag, 2012). Several reasons have been proposed as to why IB scholars should make more efforts in integrating institutional perspectives in their research. Firstly, it is argued that focusing on institutions could help to answer one of the major questions in IB research, which is, "what determines the international success and failure of firms?' (Peng, 2004, p. 106). Secondly, scholars acknowledge that much of the IB and strategic management research in the past has not been particularly interested in institutions, largely because the influence of institutions on firm activities and performance was not considered significant (Meyer and Peng, 2005). Considerable differences in institutional environments between developed, emerging and transition economies have been observed, which in turn led scholars to believe that 'institutions are much more than background conditions, and that institutions directly determine what arrows a firm has in its quiver as it struggles to formulate and implement strategy and to create competitive advantage' (Meyer et al., 2009, p. 61; see also Meyer and Peng, 2005; Peng et al., 2008).

The current stream of research within IB emphasizing institutions in the context of transition economies has focused largely on internationalization of Western-based multinational enterprises (MNEs) into transition economies (Bevan et al., 2004; Cuervo-Cazurra, 2008; Gelbuda et al., 2008; Hitt et al., 2004; Jackson and Deeg, 2008; Makhmadshoev et al., 2015; Meyer, 2001; Meyer and Peng, 2005; Meyer and Vo Nguyen, 2005; Meyer et al., 2009; Peng et al., 2008). The primary empirical focus thus far has been on some transition economies, such as Russia, China, and those in Central and Eastern Europe (Gelbuda et al., 2008; Meyer, 2001; Meyer et al., 2009; Meyer and Peng, 2005; Peng et al., 2008). Other relatively underresearched and somewhat peripheral transition economies, such as those in Central Asia, the Caucasus and the Balkans, are yet to be given adequate research attention. More importantly, perhaps, it is observed that while the growing scholarly interest in institutions and institutional approaches within the field of IB is a positive sign, the North-inspired NIE approach has been the main institutional perspective adopted by this stream of research in probing into the post-socialist transition economies.

A similar trend is also observed in the stream of research on entrepreneurship and small and medium-sized enterprise (SME) development in transition economies, where the North-inspired NIE approach appears to be the dominant institutional framework adopted (e.g., Aidis, 2005; Estrin et al., 2008; Puffer et al., 2010; Smallbone and Welter, 2012; Williams and Vorley, 2017). It is argued that the development of small firms is influenced 
not only by a range of internal firm characteristics, such as 'creativity, drive and commitment of individuals', but also to a great extent by external factors created by the environments in which firms evolve and develop (Smallbone and Welter, 2001b, p.64). External factors are considered especially influential for small firm development in transition economies, because of their weak and often ineffective institutional environments. For example, Smallbone and Welter (2001a, p. 260) state that 'in transition economies, the dominant feature influencing the nature and pace of entrepreneurship and small business development is the external environment, which, in some cases, appears hostile in social, economic and political terms'.

The adoption of North's (1990) framework has allowed some studies to distinguish between formal and informal institutional barriers. For example, barriers relating to general regulatory environments, which include tax rates and changes to tax regulations, are categorized as formal barriers (barriers created by formal institutions), whereas barriers relating to lack of law enforcement, corruption and unfair competition are categorized as informal barriers (barriers created by informal institutions) (Aidis, 2005; Smallbone and Welter, 2012). Some studies also categorize social connections and networking practices as important features of the informal institutional environment in transition economies (Aidis, 2005; Estrin et al., 2008; Makhmadshoev and Crone, 2014; Smallbone and Welter, 2012), and suggest that the prevalence of these practices indicates 'the absence of a well-functioning formal institutional framework' (Estrin et al., 2008, p.28). However, their impact on entrepreneurship and firm growth is viewed not only as adverse (for example, in the Russian environment) but also as favourable (in the Chinese environment) (Estrin et al., 2008), which suggests that it can be misleading to attribute informal institutional factors as barriers only. Informal institutions are indeed gaining more attention in this research area, as demonstrated in a review study by Manev and Manolova (2010), who call for more studies to focus on understanding informal institutional environments and their impact on entrepreneurship in transition economies.

The discussions above illustrate that the neo-institutionalist approach, and in particular the North-inspired NIE perspective, continues to provide researchers in the IB and the SME and entrepreneurship fields with a powerful tool to unpack the various complexities of the transitional context and grasp their varying implications on firms. It is argued here that this current institutional thinking on transition economies can be potentially further enhanced and enriched by infusing and integrating insights from the two relatively underexploited institutional approaches on institutional divergence and institutional change. In the sections that follow I attempt to 
demonstrate their compatibility with the dominant NIE approach, as well as their utility for the transitional periphery.

\section{INSTITUTIONAL DIVERGENCE AND VARIETIES OF TRANSITION}

A key argument advanced by this stream of research is that not only institutions matter, but so do differences in institutions. While the neoinstitutional approach continues to be influential and effective, recent contributions from other social science disciplines, particularly political economy and economic sociology, have drawn attention to the widening institutional divergence among transition economies. It is one of the main aims of this chapter to emphasize the divergent paths of transition experienced in some countries in transitional periphery and point to this embryonic varieties of transition (VoT) approach, also referred to as the 'varieties of post-socialism' or 'varieties of capitalism in post-communist countries', which places emphasis on understanding the implications of institutional divergence in the former socialist economies on economic and social behaviour.

The VoT takes its roots from the 'varieties of capitalism' (VoC) debate. The latter was originated by political economists (Amable, 2003; Hall and Soskice, 2001) and represents a dominant approach to comparative capitalism (CC) adopted in business and management literature. This approach helps to understand not only the differences in institutional structures across countries with capitalist systems (Hall and Soskice, 2001), but also the internal diversity within national contexts (Lane and Wood, 2009). Amable (2003) states that the VoC thinking was originally triggered by observed differences in macroeconomic performances among the group of developed countries (notably the United States, European countries and Japan). A key feature of this literature is the notion of institutional complementarity. According to Hall and Soskice (2001, p. 17), 'two institutions can be complementary if the presence (or efficiency) of one increases the returns from (or efficiency of) the other'. The extent of institutional complementarity may serve as an indicator of the diversity in institutional frameworks between different forms of market economies (Hall and Soskice, 2001). This work has delineated distinct national models of capitalism among developed economies, such as Hall and Soskice's (2001) division of liberal versus coordinated market capitalism. In this way, the $\mathrm{CC}$ literature draws the attention of researchers to the complex and diverse 'topography of institutional landscapes' (Jackson and Deeg, 2008, p. 541) and suggests the need to incorporate a more sophisticated and contextually 
rich characterization of institutional environments (Michailova, 2011; Redding, 2005).

Yet, when it comes to considering the institutional environments of transition economies, this dominant CC literature is silent (Makhmadshoev et al., 2015). Indeed, the relevance and applicability of the established CC frameworks to transition economies have been questioned (Havrylyshyn, 2006; Myant and Drahokoupil, 2012). Scholars observe that the CC literature tends to assume that institutional configurations are permanent or subject to only gradual change, whereas transition economies are, by their nature, subject to continuous institutional change and uncertainty (Myant and Drahokoupil, 2012). Furthermore, in the case of the former Soviet Union and especially the transitional periphery, it is observed that the transition process has not followed the linear progression towards the established models of capitalism, which was initially anticipated by policy-makers and scholars alike. Thus, as an alternative to the mainstream CC literature discussed above, Makhmadshoev et al. (2015) identified a distinct and emergent strand of work, though dominated by political scientists and economic sociologists to date, that seeks to identify, classify and accentuate varieties of capitalism in post-communist or transition countries (Feldmann, 2006; Lane and Myant, 2007).

This approach basically argues that the process of transforming planned economies into well-functioning market economies has taken a distinct trajectory in each country, and one that may be characterized by pathdependence. As a result, these divergent paths of transition have resulted in an institutional diversity among the former Soviet republics (Blackmon, 2007; Havrylyshyn, 2006). Thus, borrowing from the CC approach, the VoT camp identifies a number of different emerging models of capitalism in transition economies. For instance, Lane (2007) proposes a threefold typology comprising state-led capitalism, hybrid state/market uncoordinated capitalism, and the transition laggards characterized by statist economies (see Table 1.1). Similarly, Havrylyshyn (2006) identifies four types of transition currently prevailing in post-communist states, namely liberal societies, intermediate regimes, captured states and lagging reformers (see Table 1.2). Furthermore, Myant and Drahokoupil (2011) propose the following fivefold typology of the 'varieties of capitalism in transition': foreign direct investment (FDI)-based market economies; peripheral market economies; oligarchic or clientelistic capitalist economies; order states; and remittance- and aid-dependent countries (see Table 1.3).

This literature also questions the general assumption that the former communist countries embarked on the process of transition from similar starting points. This is because from an economic point of view some countries were significantly better than others before the collapse of 
Table 1.1 Typology of emerging capitalisms in post-communist states, as per Lane

\begin{tabular}{|c|c|}
\hline Post-communist states & Typology \\
\hline $\begin{array}{l}\text { State-led capitalism: } \\
\text { Slovenia, Czech } \\
\text { Republic, Poland, } \\
\text { Hungary, Slovakia, } \\
\text { Estonia, Lithuania, } \\
\text { Croatia, Latvia, } \\
\text { Romania, Bulgaria }\end{array}$ & $\begin{array}{l}\text { Closest to 'Continental' form of market capitalism; } \\
\text { levels of marketization and privatization comparable } \\
\text { to Organisation for Economic Co-operation and } \\
\text { Development (OECD) states; high exposure to the } \\
\text { global economy and large private sectors; embedded } \\
\text { welfare states make them comparable to continental } \\
\text { European model of capitalism; some have greater } \\
\text { state coordination, but all have developed economic, } \\
\text { political and societal preconditions of capitalism. } \\
\text { Extent of transition: transition almost complete. }\end{array}$ \\
\hline $\begin{array}{l}\text { Hybrid state/market } \\
\text { uncoordinated } \\
\text { capitalism: } \\
\text { Russian Federation, } \\
\text { Ukraine, Kazakhstan, } \\
\text { Georgia, Moldova }\end{array}$ & $\begin{array}{l}\text { Economically poorer group, with high levels of } \\
\text { poverty, inflation and unemployment; weak } \\
\text { governing institutions led to 'unsuccessful' period } \\
\text { of transition and a period of 'chaotic capitalism'; } \\
\text { pursued privatization, but exposure to the } \\
\text { global economy remains low; have low levels of } \\
\text { domestic investment; contexts characterized by } \\
\text { high institutional uncertainty, corruption, and } \\
\text { rent-seeking entrepreneurs; all countries lack } \\
\text { psychological, political and societal preconditions to } \\
\text { support modern capitalism. } \\
\text { Extent of transition: only group to assume a } \\
\text { 'transitionary' status. }\end{array}$ \\
\hline $\begin{array}{l}\text { Transition laggards or } \\
\text { statist economies: } \\
\text { Uzbekistan, } \\
\text { Turkmenistan, Belarus }\end{array}$ & $\begin{array}{l}\text { Countries in the group deemed not to have made } \\
\text { breakthrough to a capitalist system; contexts } \\
\text { characterized by high levels of state coordination } \\
\text { and bureaucratic control, and low levels of private } \\
\text { ownership and exposure to the global economy; } \\
\text { key economic functions, internal and external, } \\
\text { continue to be controlled by the state or state-owned } \\
\text { corporations. } \\
\text { Extent of transition: no significant progress toward the } \\
\text { transition. }\end{array}$ \\
\hline
\end{tabular}

Source: Complied by author from Lane (2007, pp. 35-37).

the communist regime. For instance, Central and Eastern European countries (CEECs) already had higher levels of industrialization compared to many smaller countries, which had significantly weaker levels of industrialization and served primarily as producers and suppliers of 
Table 1.2 Variation in transition outcomes in post-communist states, as per Havrylyshyn

\begin{tabular}{|c|c|}
\hline Post-communist states & Key characteristics \\
\hline Liberal societies: & Developed and well-functioning market economies; \\
\hline Estonia, Latvia, & \\
\hline Lithuania, Czech & avoided development of oligarchic tendencies; \\
\hline Republic, Hungary, & high performance on economic and social indicators; \\
\hline Poland, Slovenia, & most countries achieved European Union (EU) \\
\hline Slovakia, Croatia, & membership; \\
\hline Bulgaria, Romania & transition is complete in most countries. \\
\hline \multirow{4}{*}{$\begin{array}{l}\text { Intermediate regimes: } \\
\text { Albania, Macedonia, } \\
\text { Bosnia-Herzegovina, } \\
\text { Serbia, Georgia, } \\
\text { Ukraine, Kyrgyzstan }\end{array}$} & Significant degree of rent-seeking and oligarchic \\
\hline & $\begin{array}{l}\text { tendencies in the economy and state policy, but } \\
\text { receding; }\end{array}$ \\
\hline & $\begin{array}{l}\text { mid-range performance on economic and social } \\
\text { indicators; }\end{array}$ \\
\hline & $\begin{array}{l}\text { future EU membership gives reform incentive to some; } \\
\text { gradually but firmly moving towards liberal states. }\end{array}$ \\
\hline Captured states: & Existence of powerful 'economic oligarchy'; \\
\hline $\begin{array}{l}\text { Russian Federation, } \\
\text { Kazakhstan, } \\
\text { Azerbaijan, } \\
\text { Moldova, Armenia, } \\
\text { Tajikistan }\end{array}$ & $\begin{array}{l}\text { low levels of competition in economy and state policy; } \\
\text { insufficient evolution toward market institutions; } \\
\text { economic and social indicators on the lower end of } \\
\text { scale; } \\
\text { transition very slow and sluggish in most cases. }\end{array}$ \\
\hline Lagging reformers: & Limited progress in terms of market reforms; \\
\hline $\begin{array}{l}\text { Belarus, Turkmenistan, } \\
\text { Uzbekistan }\end{array}$ & $\begin{array}{l}\text { insignificant liberalization and privatization; } \\
\text { role of state in the economy and polity remains } \\
\text { dominant; }\end{array}$ \\
\hline & transition in all of these countries 'has barely started'. \\
\hline
\end{tabular}

Source: Compiled by author from Havrylyshyn (2006, pp. 261-263).

raw materials during the Soviet rule. In addition, there are countries in the Commonwealth of Independent States (CIS) that were significant oil and gas producers and possessed vast reserves of natural resources. This means that smaller countries with weak industrial capacities and insignificant oil and gas resources faced a tougher transition path compared to the other two groups (Myant and Drahokoupil, 2011, p.xix). Subsequent divergence in transition paths was further influenced by a broad policy approach adopted by major international institutions that somewhat erroneously assumed that a generic policy package, consisting of two opposing methods of 'shock-therapy' and 'gradualism', would be appropriate to all transition countries (ibid.). They failed to consider 
Table 1.3 Varieties of capitalism in transition economies, as per Myant and Drahokoupil

\begin{tabular}{|c|c|}
\hline Varieties of capitalism & Key characteristics \\
\hline $\begin{array}{l}\text { FDI-based market } \\
\text { economies: } \\
\text { Central-Eastern } \\
\text { European countries }\end{array}$ & $\begin{array}{l}\text { Democratic political systems and EU integration; } \\
\text { strong export structures built around inbound FDI; } \\
\text { second-rank positions within global value chains; } \\
\text { sound domestic environments for private sector } \\
\text { growth. }\end{array}$ \\
\hline $\begin{array}{l}\text { Peripheral market } \\
\text { economies: } \\
\text { The Baltics and South- } \\
\text { Eastern European } \\
\text { countries }\end{array}$ & $\begin{array}{l}\text { Democratic political systems and EU membership; } \\
\text { conducive institutions for private sector development; } \\
\text { less stable export structure based on manufacturing; } \\
\text { weak domestic economies and open to external } \\
\text { shocks; } \\
\text { dependence on remittances and lower welfare } \\
\text { provisions. }\end{array}$ \\
\hline $\begin{array}{l}\text { Oligarchic or clientelistic } \\
\text { capitalism: } \\
\text { Most countries in the } \\
\text { CIS }\end{array}$ & $\begin{array}{l}\text { Close ties between business and politics; } \\
\text { weakly developed environment for new businesses; } \\
\text { levels of social and employment protection are low; } \\
\text { weak exports and low levels of domestic investment; } \\
\text { 'relatively authoritarian political systems'. }\end{array}$ \\
\hline $\begin{array}{l}\text { Order state capitalism: } \\
\text { CIS countries with } \\
\text { limited reforms }\end{array}$ & $\begin{array}{l}\text { Some degree of integration into the global economy; } \\
\text { prevalence of state ownership and control of } \\
\text { economy; } \\
\text { exports dominated by commodities and raw } \\
\text { materials; } \\
\text { also characterized by 'authoritarian political } \\
\text { systems'. }\end{array}$ \\
\hline $\begin{array}{l}\text { Remittance- and aid- } \\
\text { based economies } \\
\text { Low-income CIS and } \\
\text { Eastern European states }\end{array}$ & $\begin{array}{l}\text { Weak bases for economic transformation; } \\
\text { weak environments for private sector development; } \\
\text { adversely affected by peripheral geographical } \\
\text { locations; } \\
\text { dominated by domestic-oriented entrepreneurship; } \\
\text { potential to develop into MNE subcontracting } \\
\text { locations. }\end{array}$ \\
\hline
\end{tabular}

Source: Compiled by author from Myant and Drahokoupil (2011, pp.310-312).

specific policy needs of individual countries and instead focused on the agenda to prioritize speedy implementation of different transitional requirements, such as liberalization of prices, international trade and banking activities, legalization of private enterprise, privatization, and sharp minimization in state intervention. While this approach indeed benefited some countries, it did not produce expected results in countries 
with weaker capacities to absorb and implement the suggested policy package, thereby necessarily affecting the outcomes of the transition process in these countries.

Whilst many of these states continue to be collectively labelled as transition economies, and may be deemed to have similar political economies, the aforementioned literature highlights the significant divergence that has taken place in the nature and direction of transition among the group. The tables and their classifications suggest that the nature and outcomes of transition appear to vary significantly; authors report that whilst many countries have completed the process, and many others are in the process of transformation, there are also a number of countries where the transition has barely commenced. Further, it is noted here that this diversity of transition shapes the process of institutional development and influences the specific type of market economic system that is being constructed in particular countries (Myant and Drahokoupil, 2012). This implies significant variation in these countries' (emerging) institutional contexts. It is important to acknowledge that attempts have been made in the aforementioned business and management literature to emphasize the heterogeneity in institutional contexts. For instance, IB scholars distinguish between the 'big bang' versus the more gradual model of transition adopted by the larger economies of Russia and China, respectively (Buck et al., 2000; Hitt et al., 2004; Tsang, 1996), while the SME and entrepreneurship scholars distinguish between transition economies with more advanced and less advanced market reforms (Smallbone and Welter, $2001 \mathrm{~b}, 2012$ ). However, it is observed that no corresponding attention has been paid to smaller post-Soviet economies in the periphery, and more importantly, no conceptual link has been made to this particular strand of comparative institutionalism literature, which places emphasis on the direction and nature of the transition process, in addition to the speed of transition (Makhmadshoev et al., 2015). This suggests a need to better understand the implications of the varieties of transition on firm behaviour. This observation is particularly timely, given that the comparative institutionalism approach is rapidly gaining ground within wider business and management literature (Jackson and Deeg, 2008; Hall and Soskice, 2001; Hotho and Pedersen, 2012).

\section{Utility of the VoT for the Transitional Periphery: Some Empirical Evidence}

As stated in the previous section, a key argument of the VoT approach is that the formerly planned economies may be developing diverse national institutional environments as a result of experiencing divergent paths to the transition process. By drawing upon insights obtained through 
original fieldwork in Central Asia and integrating these with empirical evidence gathered from publicly available sources, this section demonstrates the usefulness of this argument and further cautions researchers that it may be erroneous to attribute countries in the transitional periphery, and indeed transitional countries in general, as a homogeneous category in relation to their institutional configurations (Makhmadshoev et al., 2015).

One of the key and somewhat unanticipated findings of the fieldwork conducted in the Central Asian countries of Kyrgyzstan and Tajikistan was that despite their similarities and common Soviet heritage, the institutional environments of the two countries were found to be similar but different. This partly accounted for differences in the impact of institutional contexts on firm behaviour in the two countries. Tajikistan gained independence in September 1991 following the break-up of the Soviet Union and almost immediately entered a state of civil war, which ended only in 1997 (Heathershaw, 2009). This political reality effectively delayed, and perhaps even derailed, the start of the transition process, and the country was unable to fully initiate the programme of structural reforms until the end of the crisis (EBRD, 2002; Rakhimov et al., 2003). In contrast, Kyrgyzstan avoided any major internal conflicts after gaining independence. With the West-oriented, liberal-minded Askar Akayev elected as its first President, Kyrgyzstan rapidly adopted a radical transition programme promoted by major international organizations such as the International Monetary Fund (IMF) and the World Bank, which in turn was informed by the so-called Washington Consensus (Myant and Drahokoupil, 2011, p.xx), and focused on pursuing important measures to stabilize the macroeconomic and financial situation, liberalize prices and commercial activity, and promote privatization and denationalization (Dabrowski and Antczak, 1995; Jermakowicz et al., 1995). Subsequently, in 1993, it became the first of the CIS countries to introduce its own currency (Slay, 1995), and one of the first to liberalize its foreign trade (Dabrowski and Antczak, 1995). Success in economic reforms soon resulted in Kyrgyzstan becoming the first of all former Soviet republics to gain membership in the World Trade Organization (WTO), in 1998, an important milestone for the economic (re)integration of Kyrgyzstan with the outside world.

Tajikistan, at least initially, has been included in the category of 'slow reformers' along with the likes of Belarus, Turkmenistan and Uzbekistan (EBRD, 2002, p. 79). According to the World Bank (2013a), which provides one of the widely used indicators for regulatory reforms, Tajikistan's business regulations are one of the least favourable amongst the former Soviet republics, including those in the transitional periphery (see Table 1.4). 


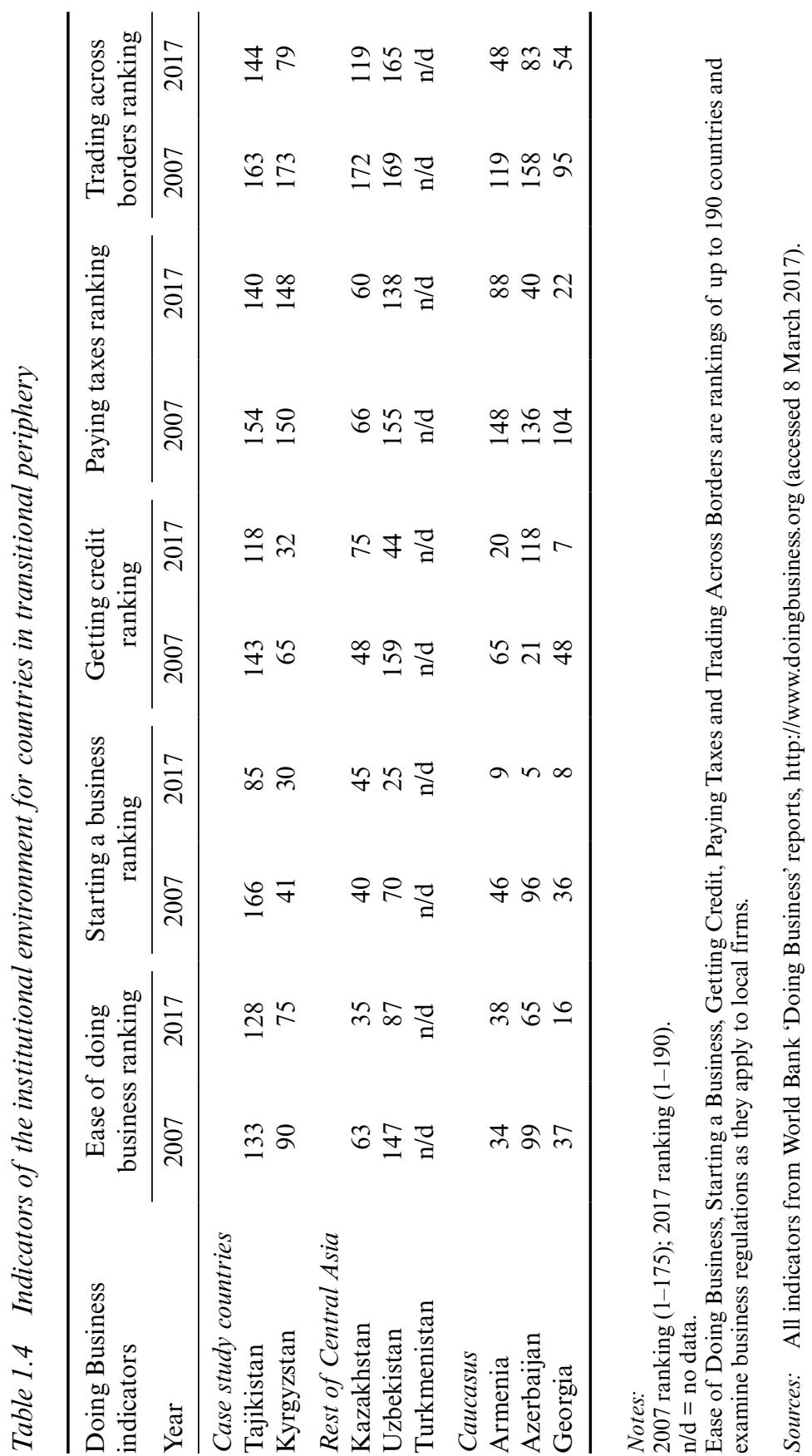


It stands at 128 in the overall ranking of 190 countries on Ease of Doing Business, which does not compare favourably with other countries in the transitional periphery. However, in terms of reforms relating to economic integration, some important and positive steps have been taken in order to liberalize foreign trade, remove cross-border barriers to trade, and attract foreign direct investment (FDI). For example, a resolution was adopted by the government on foreign trade liberalization in 1995 (UNESCAP, 2001); export duties were abolished to facilitate foreign trade; and new legislation on foreign investment was adopted in 1992 to attract FDI and encourage foreign investors to participate in privatization. With the introduction of a new law on investments in 2007, significant legal improvements were made in protecting the rights of investors (World Bank, 2013b). In addition, Tajikistan applied for membership of the WTO in 2001, and after many years of negotiations was accepted as a member in 2013, becoming only the second country in Central Asia, following the Kyrgyz Republic, to achieve this (Kazakhstan also joined later in 2015).

According to various observers, Kyrgyzstan's business regulations are some of the most favourable amongst the former Soviet republics, and considerably more favourable when compared to other countries in the Central Asian periphery (perhaps excluding Kazakhstan, which has moved up the World Bank rankings in recent years). It appears to have achieved the most progress in reforms among its Central Asian neighbours in accordance with the European Bank for Reconstruction and Development (EBRD)'s transition indicators, and its average score of the six indicators suggests that its progress has been almost comparable to Armenia and Georgia, making them the three leading countries in terms of reforms in the transitional periphery (see Table 1.5). A number of key regulatory improvements have been made in Kyrgyzstan in areas of taxation and foreign trade, which have had a positive impact on domestic and international activities of firms. Further to abolishing export duties in the early 1990s, and reducing the number of export documents (World Bank, 2013c), in 2008 the implementation of the Single Window project commenced in Kyrgyzstan, which was aimed at facilitating foreign trade by means of simplifying customs procedures and reducing various inefficiencies and costs associated with imports and exports.

Also worthy of discussion are the observed differences in the political sphere that may have acted as an important factor behind the divergent transition processes in the two countries, and which may have contributed to the development of potentially different institutional environments for firms (see, e.g., Makhmadshoev and Crone, 2014; Makhmadshoev et al., 2015). In particular, Kyrgyzstan's unprecedented changes in its political landscape over the last decade have cemented a certain revolutionary 


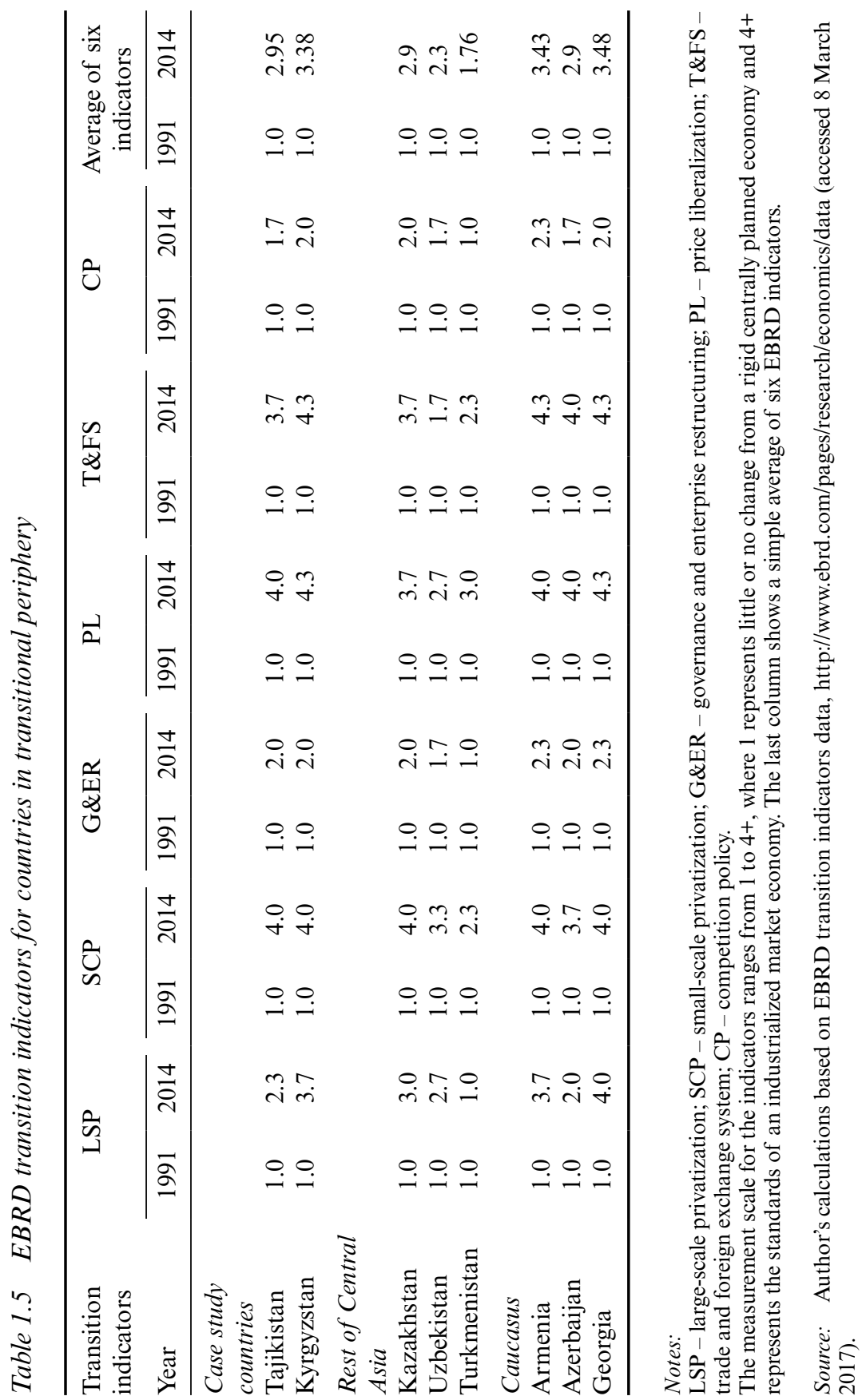


culture in the country, indicating the apparent determination of its people to reject authoritarianism and instead push further towards democracy and economic freedom. Indeed, Kyrgyzstan, unlike many of its postSoviet neighbours, followed a more liberal and a more democratic path to transition (Matveeva, 2009). Askar Akayev, the first president elected after independence, became a popular figure in the West for his open and liberal views, and was famously described as a 'Jeffersonian democrat in the heart of Asia' (Merry, 2004, p. 296). However, a series of 'authoritarian moves' by Akayev in the late 1990s and early 2000s, such as stricter control of mass media, election rigging and increasing nepotism, led to the Tulip revolution in 2005, which saw the dramatic overthrow of his regime (Collins, 2009; Tudoroiu, 2007, p. 331). Despite such an extraordinary end to his rule, many still consider Akayev, formerly a member and head of the Kyrgyz Academy of Sciences, a key architect of Kyrgyzstan's more liberal and progressive transition course. This historic event, the first of its kind in the post-Soviet Central Asia, set the stage for the subsequent overthrow in 2010 of Akayev's successor, Kurmanbek Bakiev, who was overthrown for reasons similar to his predecessor. In 2010 Roza Otunbayeva became an interim president, until Almazbek Atambayev became the newly elected president of the Kyrgyz Republic in December 2011. In accordance with the Constitution, the country elected a new president in October 2017, Sooronbay Jeenbekov, and for the first time in post-Soviet Central Asia power was transferred peacefully from one elected president to another.

In neighbouring Tajikistan, by contrast, the government vowed to undertake structural changes and implement market reforms in the early years of transition, and thereby appealed for technical and financial assistance from foreign governments and international organizations. Yet, almost three decades into the transition, some core features of the planned economy remain widespread, such as the state monopoly of economically important sectors, control over exchange and interest rates, and state intervention in the banking sector (EBRD, 2010, 2012). Coupled with hesitation by the state over taking on the implementation of market reforms more rigorously, it is likely that instead of a market system Tajikistan may be heading towards some form of state capitalism, if any form of capitalism at all. Thus far the nature of transition in Kyrgyzstan has been fundamentally different to any of the countries in the Central Asian periphery, but comparable to that of Georgia in the Caucasus, where a similar Rose revolution took place in 2003 which saw the fall of the Shevarnadze regime (Tudoroiu, 2007). This served as a basis for implementing liberal market reforms, opening the economy to competition and investment, and fostering stronger ties with the West. The parallels that can be drawn between the transition experiences of Georgia and Kyrgyzstan 
suggest that their national institutional environments, and subsequently their effects on firms, are bound to be different when compared to other countries in the transitional periphery. This chapter's analysis and the empirical evidence provided in the tables also suggest that countries in the transitional periphery are, in effect, moving from institutional convergence to institutional divergence.

Table 1.6, which is a summary of fieldwork responses to how firms in Tajikistan and Kyrgyzstan perceive their national institutional environments, supports the VoT argument on the existence of divergence in the outcomes of transition. In particular, analysis of the findings suggests that formal institutions in Kyrgyzstan are generally more advanced (that is, better designed) from a regulatory point of view. This was found to have a positive influence on firm behaviour (note that the firms studied were SMEs in the cotton, textile and garment sectors in the two countries). It was also suggested that formal institutions have a positive impact on firm activity because they help to reduce formal and informal transaction costs. Firms in Kyrgyzstan were observed to incur lower transaction costs because more developed formal institutions, in principle, suggest more efficient transactions. Accordingly, a more advanced formal institutional environment in Kyrgyzstan suggests a more successful transition to the market mechanism and, thus, lower transaction costs for firms. North (1990) indicates that the underlying institutional frameworks in the society can either reinforce or discourage firms from engaging in economic activity. Research findings on formal institutions seem to reflect this assumption. Formal institutions in Tajikistan act to increase transaction and production costs, create a range of regulatory obstacles to exporting, and provide few (if any) incentives for firms; whereas in Kyrgyzstan, formal institutions generally act to reduce transaction costs and export-related regulatory barriers and, in addition, provide certain incentives for firms to engage in the production and exports of textiles and garments. This comparative example clearly illustrates diversity in formal institutional contexts, as well as how institutions can both constrain and facilitate firms' economic activities.

In understanding the variation in the influence of informal institutions between the two countries, the key explanation lies, at least partly, with the quality of formal institutions and the mechanism of their enforcement and implementation, which according to the $\mathrm{CC}$ and VoT theorists amounts to institutional complementarity. In this study, formal institutions were found to be more advanced and more effectively enforced in Kyrgyzstan compared to Tajikistan. For instance, lower tax rates and the simplified system of tax calculation in the Kyrgyz case signal more optimal tax rules, and thus more advanced formal institutions. This shows the intent of the 


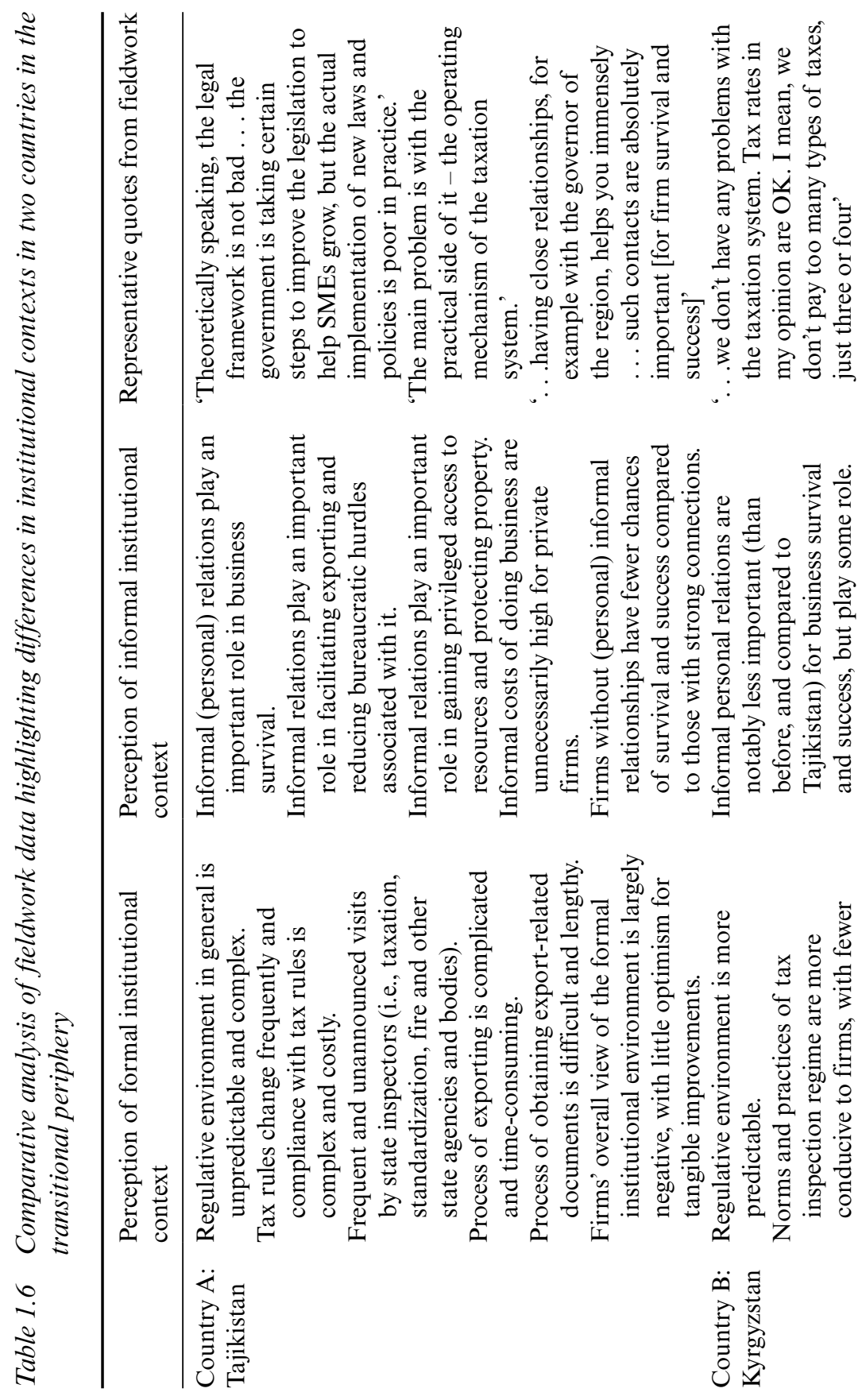




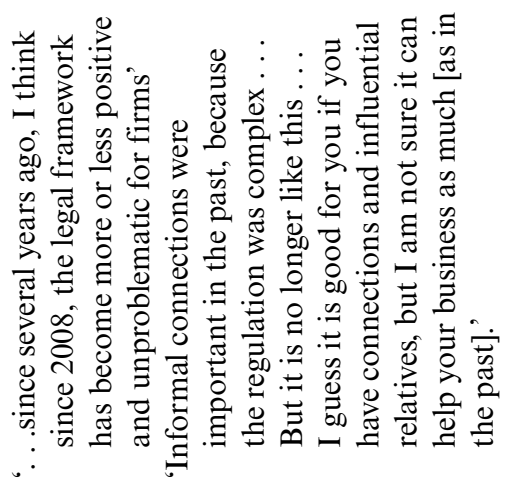

芯 芯志导
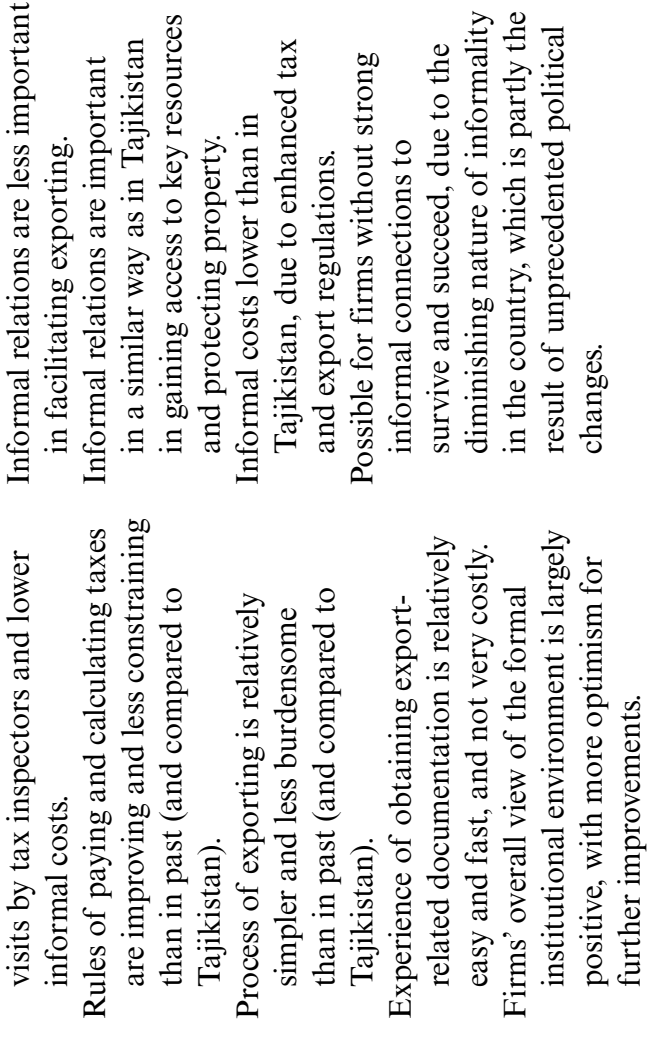
Kyrgyz state to create a regulatory environment which encourages competition (by enabling more firms to enter the private sector) and discourages state intervention (by reducing the influence of tax inspectors on firms), thereby making the regulatory environment more in line with the principles of the market economy (Furubotn and Richter, 2000). The relatively strong implementation of this law has added more transparency in interactions between state officials and businesses and, importantly, resulted in a significant decline of the level and frequency of informal payments made by firms to tax officials. This example demonstrates how more advanced formal institutions have contributed to reforming undesirable informal institutions by making the latter less prevalent, and thus less constraining for firms. This portrays a contrasting yet analytically consistent picture with regard to the case of Tajikistan, where the reverse line of argumentation (that is, weak formal institutions contributed to informal institutions becoming more prevalent, and thus more constraining for firms) was found to be applicable. Indeed, it was one of the key emerging findings of the fieldwork that institutions have developed, and therefore function, differently in the two seemingly similar post-Soviet states; consequently, their influence on firm behaviour appears to vary also.

\section{ACTOR-CENTRED PERSPECTIVE ON INSTITUTIONAL CHANGE}

Though I do not offer empirical evidence to support the utility of this institutional perspective, I argue conceptually for its importance and relevance in furthering the current thinking on institutions and the firm in the transition periphery. An increasing number of scholars have recently called for more attention to be given to better understanding the role of economic actors, as well as the mechanisms they deploy, in shaping the process of institutional change in transition economies (Kalantaridis, 2007; Puffer et al., 2010; Welter and Smallbone, 2011). This can be seen as part of the broader debate to give greater emphasis to agency in institutional research, which is described by Carney et al. (2009, p. 361) as 'the second movement in institutional theory'. In response to this call, one can point to the pertinence of an emerging yet hitherto underexplored perspective on institutional change, which is informed by the works of Campbell (1997, 2004) in the areas of rational choice institutionalism and institutional economics. Though the neo-institutional perspective discussed earlier, and in particular the seminal work of North (1990), places considerable emphasis on understanding the process of institutional change and its importance for economic development (North, 2005), a key limitation of 
this approach is that the mechanisms through which institutional change may be manifested are, arguably, poorly specified (Campbell, 2004). Indeed, as the review of this approach earlier demonstrated, emphasis is placed predominantly on unpacking the meaning of institutions and analysing how they interact and change at a macro level. Thus, Campbell (2004, p. 88) argues that 'any account of how institutions are built or affect social behaviour requires a micro-level account of actors as causal agents'. Examining the utility of the approach which places more emphasis on actors or firms as institutional players in probing into the transition economies, albeit conceptually, fits well with the broader objective of this book, which is to advance more firm-centred perspectives.

It has been suggested by a number of institutionally focused scholars that the emergence of capitalist institutions in the former planned economies follows a certain path-dependent or evolutionary process (Campbell, 2004; Smallbone and Welter, 2006; Welter and Smallbone, 2011). This is reflected in the reality where the formal institutions in many transition economies are being replaced and redesigned, but the informal institutions developed during the Soviet times and entrenched in norms and traditions continue to dominate economic and social behaviours, including those of the firm (Peng and Heath, 1996). While scholars use the concept of pathdependence to examine the development of economic institutions in post communist countries (Manolova et al., 2010; Smallbone and Welter, 2012; Stark and Bruszt, 1998; Zweynert, 2006), what has often been missing in such analyses is elaboration of the specific mechanisms through which path-dependent institutional change could be manifested and explained (Kalantaridis, 2007). As Campbell (2004, p. 66) states in this regard, 'the difficulty is that the mechanisms whereby path-dependent effects occur are often poorly specified, if not completely neglected'. To address this limitation, the concept of 'bricolage' is identified, which is underexploited in institutional studies (with the exception of some, including Carney et al., 2009; Lanzara, 1998; Phillips and Tracey, 2007), yet represents a notion well suited to enhancing our understanding of path-dependent evolutionary institutional change: the type that prevails in countries transitioning from communism to capitalism (Campbell, 2004). This section now turns to analysing the pertinence of bricolage.

\section{Bricolage}

Originally introduced by anthropologist Claude Levi-Strauss, the term 'bricolage' characterizes a certain way of acting in the society whereby actors use existing resources and instruments, or 'whatever is at hand', to make do (Levi-Strauss, 1966, p. 17). Baker and Nelson's (2005) seminal 
paper is widely viewed to have laid the foundations for building the theory of bricolage in entrepreneurship and wider management research. They define bricolage as 'making do by applying combinations of the resources at hand to new problems and opportunities' (Baker and Nelson, 2005, p.333). According to this definition, 'making do' refers to a specific attitude of actors in refusing to accept the various institutional limitations imposed by their operating environments. Instead, they focus on combining a variety of existing resources available cheaply or freely - including skills, capabilities, financial and physical resources - to create new solutions to problems or to explore new business opportunities. Stinchfield et al. (2013) posit that resources at hand may include 'physical, artifacts, skills or ideas' that actors can draw upon when faced with opportunities or obstacles. Baker and Nelson (2005) further suggest that actors can engage in bricolage across five areas or domains, namely physical inputs, labour inputs, skills inputs, customers and markets, and institutional and regulatory environment.

Thus, actors can make do not only by redesigning and reapplying physical and social resources, but also by reshaping a variety of institutional and regulatory elements available at hand. Indeed, a growing number of studies have emphasized the institutional utility of bricolage (DiDomenico et al., 2010; Fisher, 2012; Phillips and Tracey, 2007). Among these are Carney et al. (2009), who suggest that the concept is highly relevant in understanding the process whereby actors combine different institutional elements to develop new types of institutions or reconfigure existing ones to address new challenges. In a similar spirit, Desa (2012) and Mair and Marti (2009) have also demonstrated how actors engage in bricolage to fill various voids in resource-depleted and institutionally challenging environments. The former, for instance, noted that 'bricolage acts as an entrepreneurial response mechanism that reconfigures macro institutional environments' (Desa, 2012, p. 743).

Importantly, scholars also suggest that bricolage as a mechanism is not just about creating something from resources available at hand, or bringing together different institutional elements to address a certain problem, but is also about shaping the process of institutional development (Carney et al., 2009; Campbell, 2004; Desa, 2012; Mair and Marti, 2009; Phillips and Tracey, 2007). For instance, Desa (2012, p. 730) states that actors who engage in bricolage are also participants of 'a process of actor-initiated institutional change'. Campbell (2010, p. 98) who advocates bricolage specifically as a mechanism of path-dependent, incremental institutional change, describes it as the process or mechanism through which institutional change may involve 'the rearrangement or recombination of institutional principles and practices in new and creative ways'. 
Through engagement in bricolage actors can change existing institutions or create new ones by infusing elements of their old and newly imported institutional systems (Campbell, 2004). Thereby, bricolage can be seen as an appropriate, firm-centred perspective with great potential to enhance our understanding of the behaviour, activity and creativity of economic actors and firms in the context of transition economies, where institutions are, by definition, in a state of flux and where such actors can play a significant role in the formation and co-creation of institutional systems (Tracey and Phillips, 2011). In other words, the concept has potential to offer an appropriate micro-level perspective on how economic actors can influence institutions, thereby complementing the established macro-level perspective discussed earlier in the chapter on how institutional structures influence economic actors. In this way, exploring the notion of bricolage can shed fresh light on the duality between institutions and actors, and thereby contribute to furthering the current thinking on institutions and the firm in the transitional periphery.

\section{CONCLUSION}

This chapter has argued that researchers in recent years have benefited significantly by drawing on institutional theory to explore and explain the various effects of unstable institutional settings and embedded institutional factors on firm behaviour in transitional environments. It has highlighted that the neo-institutionalist approach, and in particular the North-inspired new institutional economics lens, tends to represent the most dominant approach adopted by many business and management scholars with an interest in post-socialist economies. While acknowledging that this perspective remains powerful and effective to this day, the chapter has proposed that research in this area can potentially benefit in important ways by integrating insights from two emerging, but hitherto underexploited institutional perspectives, namely comparative capitalism's varieties of transition approach and the more actor-centred perspective on institutional change. In other words, the conceptual and empirical analyses, and the suggestion to integrate insights from the two emerging institutional approaches, signify that the nature of questions asked within the literature on institutions and the firm in transition economies can, and perhaps should, be broadened to include not only various deterministic questions relating to how institutions influence the behaviour of the firm, but also what are the implications of institutional diversity on firm behaviour and what is the firm's role, if any, as a creative and rational actor in influencing the process of institutional change in these transitional environments. 
More than 25 years after the collapse of the Soviet regime, it becomes apparent that the process of transition in former Soviet republics has not followed the intended progression towards Western models of capitalism; to the contrary, various paths have emerged, resulting in the varieties of capitalism in transition economies. Literature suggests that only the Baltic states and countries of the former Communist bloc of Eastern and Central Europe can be considered to have completed the process of transition, whilst many others, including those in the periphery, have mostly stalled, stagnated or derailed. The varieties of transition approach points out that this divergence in the transition process among the former communist states translates into a great number of institutional configurations at national levels. This institutional divergence is likely to widen, resulting in further variation between national institutions, which in turn obliges researchers to start asking not only how institutions matter in transition economies, but also how differences in institutions matter. Thus, exploring the heterogeneity of institutional contexts, and placing more emphasis on understanding the increasingly important role of economic actors in influencing the process of institutional transformation, can lead researchers to important new insights on the relationship between institutions and the firm in the transitional periphery.

\section{REFERENCES}

Aidis, R. (2005), 'Institutional barriers to small- and medium-sized enterprise operations in transition countries', Small Business Economics, 25 (4), 305-318.

Amable, B. (2003), The Diversity of Modern Capitalism, New York: Oxford University Press.

Baker, T. and R.E. Nelson (2005), 'Creating something from nothing: resource construction through entrepreneurial bricolage', Administrative Science Quarterly, 50 (3), 329-366.

Bevan, A., S. Estrin and K. Meyer (2004), 'Foreign investment location and institutional development in transition economies', International Business Review, 13 (1), 43-64.

Blackmon, P. (2007), 'Divergent paths, divergent outcomes: linking differences in economic reform to levels of US foreign direct investment and business in Kazakhstan and Uzbekistan', Central Asian Survey, 26 (3), 355-372.

Buck, T., I. Filatotchev, P. Nolan and M. Wright (2000), 'Different paths to economic reform in Russia and China: causes and consequences', Journal of World Business, 35 (4), 379-400.

Campbell, J.L. (1997), 'Mechanisms of evolutionary change in economic governance: interaction, interpretation and bricolage', in L. Magnusson and J. Ottosson (eds), Evolutionary Economics and Path Dependence, Cheltenham, UK and Northampton, MA, USA: Edward Elgar Publishing, pp. 10-32. 
Campbell, J.L. (2004), Institutional Change and Globalisation, Princeton, NJ: Princeton University Press.

Campbell, J.L. (2010), 'Institutional reproduction and change', in G. Morgan, J.L. Campbell, C. Crouch, O.K. Pedersen and R. Whitley (eds), The Oxford Handbook of Comparative Institutional Analysis, New York: Oxford University Press, pp. 87-116.

Carney, M., E. Gedajlovic and X. Yang (2009), 'Varieties of Asian capitalism: toward an institutional theory of Asian enterprise', Asia Pacific Journal of Management, 26, 361-380.

Coase, R.H. (1937), 'The nature of the firm', Economica, 4 (16), 386-405.

Coase, R. (1998), 'The new institutional economics', American Economic Review, 88 (2), 72-74.

Coleman, J.S. (1988), 'Social capital in the creation of human capital', American Journal of Sociology, 94, S95-S120.

Collins, K. (2009), 'Economic and security regionalism among patrimonial authoritarian regimes: the case of Central Asia', Europe-Asia Studies, 61 (2), 249-281.

Cuervo-Cazurra, A. (2008), 'Better the devil you don't know: types of corruption and FDI in transition economies', Journal of International Management, 14, 12-27.

Dabrowski, M. and R. Antczak (1995), 'Economic reforms in Kyrgyzstan', Russian and East European Finance and Trade, 31 (6), 5-30.

Dacin, M.T., J. Goodstein and W.R. Scott (2002), 'Institutional theory and institutional change: introduction to the Special Research Forum', Academy of Management Journal, 45 (1), 45-57.

Davis, L.E. and D.C. North (1971), Institutional Change and American Economic Growth, Cambridge: Cambridge University Press.

Desa, G. (2012), 'Resource mobilization in international social entrepreneurship: bricolage as a mechanism of institutional transformation', Entrepreneurship Theory and Practice, 36 (4), 727-751.

DiDomenico, M.L., H. Haugh and P. Tracey (2010), 'Social bricolage: theorizing social value creation in social enterprise', Entrepreneurship Theory and Practice, 34 (4), 681-703.

DiMaggio, P.J. and W.W. Powell (1983), 'The iron cage revisited: institutional isomorphism and collective rationality in organisational fields', American Sociological Review, 48 (2), 147-160.

Dunning, J.H. (2004), 'An evolving paradigm of the economic determinants of international business activity', in J. Cheng and M. Hitt (eds), Managing Multinationals in a Knowledge Economy: Economics, Culture and Human Resources, Advances in International Management, Vol. 15, Elsevier: Oxford, pp. 3-27.

EBRD (2002), Transition Report 2002: Agriculture and Rural Transition, London: European Bank for Reconstruction and Development.

EBRD (2010), Transition Report 2010: Recovery and Reform, London: European Bank for Reconstruction and Development.

EBRD (2012), Commercial Laws of Tajikistan, April 2012: An Assessment by the $E B R D$, London: European Bank for Reconstruction and Development.

Estrin, S., K.E. Meyer and M. Bytchkova (2008), 'Entrepreneurship in transition economies', in A. Basu, M. Casson, N. Wadeson and B. Yeung (eds), The Oxford Handbook of Entrepreneurship, Oxford: Oxford University Press, pp. 693-725. 
Feldmann, M. (2006), 'Emerging varieties of capitalism in transition countries: industries relations and wage bargaining in Estonia and Slovenia', Comparative Political Studies, 39 (7), 829-854.

Fisher, G. (2012), 'Effectuation, causation, and bricolage: a behavioral comparison of emerging theories in entrepreneurship research', Entrepreneurship Theory and Practice, 36 (5), 1019-1051.

Furubotn, E.G. and R. Richter (2000), Institutions and Economic Theory: The Contribution of the New Institutional Economics, Ann Arbor, MI: University of Michigan Press.

Gelbuda, M., K.E. Meyer and A. Delios (2008), 'International business and institutional development in Central and Eastern Europe', Journal of International Management, 14 (1), 1-11.

Granovetter, M.S. (1973), 'The strength of weak ties', American Journal of Sociology, 78 (6), 1360-1380.

Granovetter, M.S. (1985), 'Economic action and social structure: the problem of embeddedness', American Journal of Sociology, 91 (3), 481-510.

Hall, P.A. and D. Soskice (2001), 'An introduction to varieties of capitalism', in P.A. Hall and D. Soskice (eds), Varieties of Capitalism: The Institutional Foundations of Comparative Advantage, Oxford: Oxford University Press, pp. 1-68.

Havrylyshyn, O. (2006), Divergent Paths in Post-Communist Transformation: Capitalism for All or Capitalism for the Few?, Basingstoke: Palgrave Macmillan.

Heathershaw, J. (2009), Post-Conflict Tajikistan: The Politics of Peacebuilding and the Emergence of Legitimate Order, London: Routledge.

Hitt, M.A., D. Ahlstrom, M.T. Dacin, E. Levitas and L. Svobodina (2004), 'The institutional effects on strategic alliance partner selection in transition economies: China vs. Russia', Organisation Science, 15 (2), 173-185.

Hotho, J.J. and T. Pedersen (2012), 'Beyond the "rules of the game": three institutional approaches and how they matter for international business', in G. Wood and M. Demirbag (eds), Handbook of Institutional Approaches to International Business, Cheltenham, UK: Edward Elgar Publishing, pp. 236-273.

Jackson, G. and R. Deeg (2008), 'Comparing capitalism: understanding institutional diversity and its implications for international business', Journal of International Business Studies, 39, 540-561.

Jermakowicz, W.W., J. Pankow and G. Soros (1995), 'Privatization in the Kyrgyz Republic', Russian and East European Finance and Trade, 31 (6), 31-72.

Kalantaridis, C. (2007), 'Institutional change in post-socialist regimes: public policy and beyond', Journal of Economic Issues, 41 (2), 435-442.

Kostova, T. and K. Roth (2002), 'Adoption of organisational practice by subsidiaries of multinational corporations: institutional and relational effects', Academy of Management Journal, 45 (1), 215-233.

Lane, D. (2007), 'Post-state socialism: a diversity of capitalisms?', in D. Lane and M. Myant (eds), Varieties of Capitalism in Post-Communist Countries, Basingstoke: Palgrave Macmillan, pp. 13-39.

Lane, D. and M. Myant (eds) (2007), Varieties of Capitalism in Post-Communist Countries, Basingstoke: Palgrave Macmillan.

Lane, C. and G. Wood (2009), 'Capitalist diversity and diversity within capitalism', Economy and Society, 38 (4), 531-551.

Lanzara, G.F. (1998), 'Self-destructive processes in institution building and some modest countervailing mechanisms', European Journal of Political Research, 33, $1-39$. 
Levi-Strauss, C. (1966), The Savage Mind, Chicago, IL: University of Chicago Press. Mair, J. and I. Marti (2009), 'Entrepreneurship in and around institutional voids: a case study from Bangladesh', Journal of Business Venturing, 24, 419-435.

Makhmadshoev, D. and M. Crone (2014), 'Exploring the influence of the national institutional environment on SME exporters: comparative evidence from Tajikistan and the Kyrgyz Republic', in M.T.T. Thai and E. Turkina (eds), Internationalisation of Firms from Economies in Transition: The Effects of a Politico-Economic Paradigm Shift, Cheltenham, UK and Northampton, MA, USA: Edward Elgar Publishing, pp. 303-331.

Makhmadshoev, D., K. Ibeh and M. Crone (2015), 'Institutional influences on SME exporters under divergent transition paths: comparative insights from Tajikistan and Kyrgyzstan', International Business Review, 24 (6), 1025-1036.

Manev, I.M. and T.S. Manolova (2010), 'Entrepreneurship in transitional economies: review and integration of two decades of research', Journal of Developmental Entrepreneurship, 15 (1), 69-99.

Manolova, T.S., I.M. Manev and B.S. Gyoshev (2010), 'In good company: the role of personal and inter-firm networks for new venture internationalization in a transition economy', Journal of World Business, 45, 257-265.

Matveeva, A. (2009), 'Legitimising Central Asian authoritarianism: political manipulation and symbolic power', Europe-Asia Studies, 61 (7), 1095-1121.

Merry, E.W. (2004), 'Governance in Central Asia: national in form, Soviet in content', Cambridge Review of International Affairs, 17 (2), 285-300.

Meyer, K.E. (2001), 'Institutions, transaction costs, and entry mode choice in Eastern Europe', Journal of International Business Studies, 32 (2), 357-367.

Meyer, K.E. and M.W. Peng (2005), 'Probing theoretically into Central and Eastern Europe: transaction, resources, and institutions', Journal of International Business Studies, 36 (6), 600-621.

Meyer, K.E. and H. Vo Nguyen (2005), 'Foreign investment strategies and subnational institutions in emerging markets: evidence from Vietnam', Journal of Management Studies, 42 (1), 63-93.

Meyer, K.E., S. Estrin, S.K. Bhaumik and M.W. Peng (2009), 'Institutions, resources, and entry strategies in emerging economies', Strategic Management Journal, 30, 61-80.

Michailova, S. (2011), 'Contextualizing in international business research: why do we need more of it and how can we be better at it?', Scandinavian Journal of Management, 27, 129-139.

Mudambi, R. and P. Navarra (2002), 'Institutions and international business: a theoretical overview', International Business Review, 11, 635-646.

Murdoch, J. (2000), 'Networks - a new paradigm of rural development?', Journal of Rural Studies, 16 (4), 407-419.

Myant, M. and J. Drahokoupil (2011), Transition economies: Political Economy in Russia, Eastern Europe, and Central Asia, Hoboken, NJ: Wiley-Blackwell.

Myant, M. and J. Drahokoupil (2012), 'International integration, varieties of capitalism and resilience to crisis in transition economies', Europe-Asia Studies, 64 (1), 1-33.

North, D.C. (1987), 'Institutions, transaction costs and economic growth', Economic Inquiry, 25 (3), 419-428.

North, D.C. (1990), Institutions, Institutional Change and Economic Performance, Cambridge: Cambridge University Press. 
North, D.C. (1991), 'Institutions', Journal of Economic Perspectives, 5 (1), 97-112.

North, D. (1997), 'The contribution of the new institutional economics to an understanding of the transition problem', UNU World Institute for Development Economics Research (WIDER), Annual Lectures 1, Helsinki.

North, D.C. (2005), Understanding the Process of Economic Change, Princeton, NJ: Princeton University Press.

Peng, M.W. (2003), 'Institutional transitions and strategic choices', Academy of Management Review, 28 (2), 275-296.

Peng, M.W. (2004), 'Identifying the big question in international business research', Journal of International Business Studies, 35 (2), 99-108.

Peng, M.W. and P.S. Heath (1996), 'The growth of the firm in planned economies in transition: institutions, organisations, and strategic choice', Academy of Management Review, 21 (2), 492-528.

Peng, M.W., D.Y.L. Wang and Y. Jiang (2008), 'An institution-based view of international business strategy: a focus on emerging economies', Journal of International Business Studies, 39, 920-936.

Phillips, N. and P. Tracey (2007), 'Opportunity recognition, entrepreneurial capabilities and bricolage: connecting institutional theory and entrepreneurship in strategic organization', Strategic Organization, 5 (3), 313-320.

Puffer, S.M., D.J. McCarthy and M. Boisot (2010), 'Entrepreneurship in Russia and China: the impact of formal institutional voids', Entrepreneurship Theory and Practice, 34 (3), 441-467.

Rakhimov, R., N. Kaiumov, M. Nurmakhmadov, O. Boboev, M. Kabutov and D. Kodirov (2003), 'The social policy of Tajikistan in a transition economy', Sociological Research, 42 (4), 6-37.

Redding, G. (2005), 'The thick description and comparison of societal systems of capitalism', Journal of International Business Studies, 36 (2), 123-155.

Scott, W.R. (1995), Institutions and Organisations, Thousand Oaks, CA: SAGE Publications.

Scott, W.R. (2008), Institutions and Organisations: Ideas and Interests, Thousand Oaks, CA: SAGE Publications.

Slay, B. (1995), 'Editor's introduction', Russian and East European Finance and Trade, 31 (3), 3-4.

Smallbone, D. and F. Welter (2001a), 'The distinctiveness of entrepreneurship in transition economies', Small Business Economics, 16 (4), 249-262.

Smallbone, D. and F. Welter (2001b), 'The role of government in SME development in transition economies', International Small Business Journal, 19, 63-77.

Smallbone, D. and F. Welter (2006), 'Conceptualising entrepreneurship in a transition context', International Journal Entrepreneurship and Small Business, 3 (2), 190-206.

Smallbone, D. and F. Welter (2012), 'Entrepreneurship and institutional change in transition economies: the Commonwealth of Independent States, Central and Eastern Europe and China compared', Entrepreneurship and Regional Development, 24 (3/4), 215-233.

Stark, D. and L. Bruszt (1998), Postsocialist Pathways: Transforming Politics and Property in East Central Europe, New York: Cambridge University Press.

Stinchfield, B.T., R.E. Nelson and W. Wood (2013), 'Learning from Levi-Strauss' legacy: art, craft, engineering, bricolage, and brokerage in entrepreneurship', Entrepreneurship Theory and Practice, 37 (4), 889-921. 
Tolbert, P.S. and L.G. Zucker (1996), 'The institutionalization of institutional theory', in S.R. Glegg, G. Hardy and W. Nord (eds), Handbook of Organisation Studies, Thousand Oaks, CA: SAGE Publications, pp. 175-190.

Tracey, P. and N. Phillips (2011), 'Entrepreneurship in emerging markets: strategies for new venture creation in uncertain institutional context', Management International Review, 51 (1), 23-39.

Tsang, S. (1996), 'Against "big bang" in economic transition: normative and positive arguments', Cambridge Journal of Economics, 20 (2), 183-193.

Tudoroiu, T. (2007), 'Rose, Orange, and Tulip: the failed post-Soviet revolutions', Communist and Post-Communist Studies, 40, 315-342.

UNESCAP (2001), Accession to the World Trade Organization: Issues and Recommendations for Central Asian and Caucasian Economies in Transition, Studies in Trade and Investment No. 48, United Nations Economic and Social Commission for Asia and the Pacific, New York.

Welter, F. and D. Smallbone (2011), 'Institutional perspectives on entrepreneurial behaviour in challenging environments', Journal of Small Business Management, 49 (1), 107-125.

Williams, N. and T. Vorley (2017), 'Fostering productive entrepreneurship in postconflict economies: the importance of institutional alignment', Entrepreneurship and Regional Development, 29 (5/6), 444-466.

Williamson, O.E. (1981), 'The economics of organisation: the transaction cost approach', American Journal of Sociology, 87 (3), 548-577.

Williamson, O.E. (1997), 'Hierarchies, markets and power in the economy: an economic perspective', in C. Menard (ed.), Transaction Cost Economics: Recent Developments, Cheltenham, UK and Northampton, MA, USA: Edward Elgar Publishing, pp. 1-29.

Williamson, O.E. (1998), 'The institutions of governance', American Economic Review, 88 (2), 75-79.

Wood, G. and M. Demirbag (eds) (2012), Handbook of Institutional Approaches to International Business, Cheltenham, UK and Northampton, MA, USA: Edward Elgar Publishing.

Woolcock, M. (1998), 'Social capital and economic development: towards a theoretical synthesis and policy framework', Theory and Society, 27 (2), 151-208.

World Bank (2013a), Doing Business 2013: Smarter Regulations for Small and Medium-Size Enterprises, Washington, DC: World Bank.

World Bank (2013b), Doing Business 2013: Economy Profile for Tajikistan, Washington, DC: World Bank.

World Bank (2013c), Doing Business 2013: Economy Profile for Kyrgyz Republic, Washington, DC: World Bank.

Zweynert, J. (2006), 'Economic ideas and institutional change: evidence from Soviet economic debates 1987-1991', Europe-Asia Studies, 58 (2), 169-192. 